Scientia Marina 85(3)

September 2021, 187-195, Barcelona (Spain)

ISSN-L: 0214-8358

https://doi.org/10.3989/scimar.05023.017

\title{
Distribution and changes in the sbGnRH system in Rastrelliger brachysoma males during the breeding season
}

\author{
Sinlapachai Senarat ${ }^{1}$, Jes Kettratad ${ }^{1,2}$, Wannee Jiraungkoorskul ${ }^{3}$, \\ Niwat Kangwanrangsan ${ }^{3}$, Masafumi Amano ${ }^{4}$, Akio Shimizu ${ }^{5}$, F. Gerald Plumley ${ }^{2}$, \\ Sasipong Tipdomrongpong ${ }^{6}$ \\ ${ }^{1}$ Department of Marine Science, Faculty of Science, Chulalongkorn University, Bangkok 10330, Thailand. \\ (SS) E-mail: Senarat.s@ @otmail.com. ORCID iD: https://orcid.org/0000-0002-7194-9702 \\ (JK) (Corresponding author) E-mail: Jes.K@ @ chula.ac.th. ORCID iD: https://orcid.org/0000-0002-3391-9537 \\ ${ }^{2}$ Marine Ecology and Marine Resources Utilization Research Unit, Aquatic Resources Research Institute, \\ Chulalongkorn University, Bangkok 10330, Thailand. \\ (FGP) E-mail: fffgp@yahoo.com. ORCID iD: https://orcid.org/0000-0003-1679-5867 \\ ${ }^{3}$ Department of Pathobiology, Faculty of Science, Mahidol University, Bangkok 10400, Thailand. \\ (WJ) E-mail: wannee.jir@mahidol.ac.th. ORCID iD: https://orcid.org/0000-0002-3070-280X \\ (NK) E-mail: niwat.kan@mahidol.ac.th. ORCID iD: https://orcid.org/0000-0001-6090-6689 \\ ${ }^{4}$ School of Marine Biosciences, Kitasato University, Sagamihara, Kanagawa 252-0373, Japan. \\ (MA) E-mail: amanoma@ kitasato-u.ac.jp. ORCID iD: https://orcid.org/0000-0002-1250-5247 \\ ${ }^{5}$ National Research Institute of Fisheries Science, Japan Fisheries Research and Education Agency, 2-12-4 Fukuura, \\ Kanazawa, Yokohama, Kanagawa 236-8648, Japan. \\ (AS) E-mail: aneko@affrc.go.jp. ORCID iD: https://orcid.org/0000-0002-0672-2042 \\ ${ }^{6}$ Samut Songkhram Coastal Fisheries Research and Development Centre, Department of Fisheries, \\ Samut Songkhram 75000, Thailand. \\ (ST) E-mail: tor6707sasi@gmail.com. ORCID iD: https://orcid.org/0000-0002-8070-8038
}

\begin{abstract}
Summary: Rastrelliger brachysoma is a mariculture candidate species, but reproduction in captive fish has been problematic. This report examines the difference in the HPG axis, the neuroendocrine system and the development of reproductive tissues between captive vs. wild male $R$. brachysoma. The gonadosomatic index (GSI) of sexually mature male wild $R$. brachysoma was $1.12 \pm 0.34$ and $1.94 \pm 0.26$ during the non-breeding and breeding seasons, respectively. Captive $R$. brachysoma had a GSI of $1.88 \pm 0.17$. All wild $R$. brachysoma were in the late spermatogenic stage irrespective of seasons. Immunostaining results showed that sbGnRH-immunoreactive neurons were distributed in three areas of the brain, namely the nucleus periventricularis, nucleus preopticus and nucleus lateralis tuberis. Follicle stimulating hormone and luteinizing hormone immunoreactivities were also observed in the pituitary gland. The levels of brain sbGnRH and GtH mRNA were not significantly different between the non-breeding and breeding seasons, but captive fish displayed (times or percent difference) lower mRNA levels than wild fish. These results suggest that these hormones control the testicular development in $R$. brachysoma and that the impaired reproduction in captivity may be due to their relative lower expression levels of follicle stimulating hormone and luteinizing hormone genes.
\end{abstract}

Keywords: agriculture; food; GnRH-GtH system; histology; mackerel; productivity; testis.

Distribución y cambios del sistema sbGnRH en machos de Rastrelliger brachysoma durante el período reproductivo

Resumen: Rastrelliger brachysoma es una especie candidata para la piscicultura marina, pero la reproducción de individuos cautivos de esta especie ha sido problemática. Este estudio examina las diferencias en el eje hipotálamo-hipófisis-gónada (eje HPG), junto con el desarrollo de tejidos reproductivos, entre machos cautivos y salvajes de $R$. brachysoma. El índice gonadosomático (IGS) de machos salvajes de $R$. brachysoma sexualmente maduros fue de $1.12 \pm 0.34$ y $1.94 \pm 0.26$ durante la estación no-reproductiva y reproductiva, respectivamente. Los $R$. brachysoma cautivos mostraron un IGS de $1.88 \pm 0.17$. Todos los $R$. brachysoma salvajes se encontraban en un estado de espermatogénesis tardío, independientemente de la estación. Los resultados de inmunotinción mostraron que las neuronas sbGnRH-inmunoreactivas se distribuían en tres áreas del cerebro, nucleus periventricularis, nucleus preopticus y nucleus lateralis tuberis. Se detectó inmunoreactividad para Fsh y Lh también en la hipófisis. Los niveles de mRNA de sbgnrh y gths en cerebro no fueron significativamente diferentes entre las estaciones de reproducción y no-reproducción, aunque se observaron niveles de mRNA menores (diferencia en nivel o porcentaje) en individuos cautivos que en salvajes. Estos resultados sugieren que las hormonas analizadas controlan el desarrollo testicular en $R$. brachysoma y que la inhibición de la reproducción en cautividad podría ser debida a unos menores niveles de expresión relativa de los genes de Fsh y Lh.

Palabras clave: agricultura; alimentación; sistema Gnrh-Gths; histología; caballa; productividad; testículo. 
Citation/Como citar este artículo: Senarat S., Kettratad J., Jiraungkoorskul W., Kangwanrangsan N., Amano M., Shimizu A., Plumley F.G., Tipdomrongpong S. 2021. Distribution and changes in the sbGnRH system in Rastrelliger brachysoma males during the breeding season. Sci. Mar. 85(3): 187-195. https://doi.org/10.3989/scimar.05023.017

Editor: E. Mañanós.

Received: December 10, 2019. Accepted: June 1, 2021. Published: August 13, 2021.

Copyright: ( 92021 CSIC. This is an open-access article distributed under the terms of the Creative Commons Attribution 4.0 International (CC BY 4.0) License.

\section{INTRODUCTION}

Gonadal maturation and activity in many teleost fishes are regulated by various hormones in the hypothalamic-pituitary-gonadal (HPG) axis (Nagahama 2000). The neuroendocrine factors are first secreted from the hypothalamus and transported to the pituitary gland; one of the most important hypothalamic neuroendocrine factors for gonad maturation is gonadotropin-releasing hormone $(\mathrm{GnRH})$ (King and Millar 1992, Sherwood 1997, Tucker and Hargreaves 2004). GnRH is synthesized in the preoptic area of the hypothalamus and stimulates production of two pituitary gonadotropic hormones (gonadotropins, $\mathrm{GtHs}$ ): follicle stimulating hormone (FSH) and luteinizing hormone (LH) (Quérat et al. 2001, Sherwood and Adams 2005). Many previous studies have shown that FSH is involved in oogenic and follicular growth, whereas LH promotes the maturation of oocytes and ovulation (Tyler et al. 1991, Planas et al. 1993).

The short mackerel (Rastrelliger brachysoma [Bleeker, 1851]), a multiple-spawning fish, is one of the most important fishery resources in Thailand. In 2014, 94231 t of $R$. brachysoma were caught, which was significantly lower than the approximately $128958 \mathrm{t}$ caught in 2012 (Department of Fisheries 2012 , 2014). The reduction of wild $R$. brachysoma may be due to overfishing and deterioration of their natural habitat (Department of Fisheries 2012). If the population continues to decline at this rate, $R$. brachysoma will be extinct or become ecologically insignificant in the Gulf of Thailand, and food insecurity will become a major issue in the near future. To date, this fish has been considered one of the prime marine species for aquaculture, which is established in the Samut Sakhon Fisheries, Sumut Sakhon province, Thailand. The project was quite successful in terms of survival rate from the embryonic development and larval stages (Department of Fisheries, unpublished data) to the adult stages in captivity (Senarat et al. 2019). However, sexually mature fish used in the project were obtained from a natural population. Unfortunately, under hatchery conditions, captive $R$. brachysoma caught from the wild population usually display endocrinological dysfunction, which completely prevents maturation of the reproductive system (Zohar and Mylonas 2001). It is unclear why captive fish experience the endocrine dysfunction and which neurohormones are involved (Zohar and Mylonas 2001). A better understanding of the structure and regulation of neuroendocrine systems, especially for seabreamGnRH ( $\operatorname{sbGnRH})$ as the master regulator controlling reproduction of fish (Selvaraj et al. 2009, 2012), is needed to improve the aquaculture. A study has been published on the distribution and alteration of sbGnRH and ovarian maturation in female $R$. brachysoma (Senarat et al. 2019), but no studies have been published on male $R$. brachysoma.

Though no previous knowledge of the sbGnRH system is available, there is considerable information on male $R$. brachysoma with respect to reproduction. $R$. brachysoma males have similar endocrine dysfunctions to females when reared in captivity (Senarat et al. 2019). In this study, the structural organization of the brain in wild male $R$. brachysoma was investigated together with the distribution pattern of the sbGnRH-positive cells. We used wild fish in breeding and non-breeding seasons as well as captive fish to find out the difference between them. Also, changes in the sbGnRH system were compared between wild and the captive $R$. brachysoma using their mRNA expressions.

\section{MATERIALS AND METHODS}

\section{Fish sampling}

Sexually mature wild Rastrelliger brachysoma (approx. $>16.5 \mathrm{~cm}$ in total length) were obtained from bamboo strake traps from the Upper Gulf of Thailand $\left(13^{\circ} 16^{\prime} 18.4^{\prime \prime} \mathrm{N}, 100^{\circ} 02^{\prime} 13.4^{\prime \prime} \mathrm{E}\right)$. Fish were sampled during both the non-breeding season (October to December 2013, $\mathrm{n}=28$ ) and the breeding season (January to February 2014, $\mathrm{n}=28$ ). The average ambient salinity was 26.32 in the non-breeding season and the highest salinity of 31.75 was recorded during the breeding season. During this time, the average relative temperature was $28.93^{\circ} \mathrm{C}$ and the highest was $29.05^{\circ} \mathrm{C}$ during the breeding season. Captive $R$. brachysoma (total length of approx. $18 \mathrm{~cm}$, two-year-old, $\mathrm{n}=6$ ) were reared during the breeding season in the Samut Songkhram Coastal Fisheries Research and Development Centre, Samut Songkhram Province, Thailand. Under captivity, all fish were kept in shaded concrete tanks filled with sea water from the Gulf. The temperature and salinity were $26^{\circ} \mathrm{C}$ to $29^{\circ} \mathrm{C}$ and $30-32$, respectively, and continuous aeration was maintained under an ambient photoperiod (12:12 h light-dark). Fish were fed with fresh squid and polychaetes twice daily. The experimental protocol in this study was approved by the Animal Care and Use Committee of the Faculty of Science in accordance with the guide for the care and use of laboratory animals prepared by Chulalongkorn University (Protocol Review No. 1423003). 


\section{Tissue collection and histological analysis of the brain and pituitary gland}

The brain and pituitary glands were dissected from all specimens and separated into two groups. In the first group, tissues $(n=44$, each season $=22$ in wild fish) were fixed in Davidson's fixative for $24 \mathrm{~h}$ (Dietrich and Krieger 2009). Following dehydration and embedding in paraffin, serial $5 \mu \mathrm{m}$ sections were cut under standard histological techniques (Bancroft and Gamble 2008). The longitudinal and cross sections were histologically stained with Harris's haematoxylin and eosin (Bancroft and Gamble 2008), Masson's trichrome and periodic acid Schiff (Bancroft and Gamble 2008, Dietrich and Krieger 2009) for identification of structures and cell types under light microscopy. The second group of tissues $(n=12$, each season $=6$ samples in wild fish and $n=6$ samples in captive fish) were frozen and then stored in RNAlater Stabilization Solution (QIAGEN, Hilden, Germany) at $-80^{\circ} \mathrm{C}$ until the measurement of sbGnRH and $\mathrm{GtH}$ mRNA levels.

\section{Collection and histological analysis of the testicular tissue}

The testicular tissue of the fish was dissected and weighed to determine the gonadosomatic index (GSI), which was calculated using the following formula: GSI=[testicular weight/total weight $\times 100$ ]. Subsequently, the tissues were subjected to standard histological techniques (Bancroft and Gamble 2008, Dietrich and Krieger 2009). Testicular development was determined using criteria of Dietrich and Krieger (2009).

\section{Immunohistochemistry and immunofluorescence}

\section{Immunoperoxidase detection}

This study examined the distribution of sbGnRH, FSH $\beta$ and LH $\beta$-like peptides using immunohistochemistry and immunofluorescence following the approach of Selvaraj et al. (2009) and Nyuji et al. (2012a). Briefly, the sections from histological observations were deparaffinized, rehydrated and washed in phosphate-buffered saline (PBS) pH 7.4 at $4^{\circ} \mathrm{C}(10$ $\mathrm{min}$ ). The endogenous peroxidase activity and free aldehyde groups from the fixative were blocked by immersing the section in 3\% hydrogen peroxide in $0.1 \mathrm{M}$ phosphate buffer ( $\mathrm{pH}$ 7.4) for $30 \mathrm{~min}$ at room temperature, and by incubating sections in a blocking solution, $10 \%$ normal goat serum (Vector Laboratories, Burlingame, USA) $+4 \%$ bovine serum albumin. The sections were subsequently incubated with the primary antibody at $4^{\circ} \mathrm{C}$ overnight (anti-sbGnRH, AS-691) This antibody is generated using the sbGnRH cDNA encoding an SP of 26 amino acids and a GAP of 57 amino acids (Okazawa et al. 1997) and used at 1:1000 and 1:2000 dilutions in a 0.1 M PBS. Anti-Fundulus heteroclitus (Fh) FSH $\beta$ 50-60 and anti-Fh LH $\beta$ 91106 (according to Shimizu and Yamashita 2002, Sel- varaj et al. 2009, Nyuji et al. 2012a) antibodies were used at 1:1000 and 1:2000 dilution in PBS (Selvaraj et al. 2009, Nyuji et al. 2012a). Both anti-Fh FSH $\beta$ 50-60 and anti-Fh LH $\beta$ 91-106 antibodies were generated with antisera raised against synthetic peptides (Shimizu and Yamashita 2002). After three rinses, the sections were incubated in the biotinylated goat anti-rabbit IgG solution (1:500), stained with 30, 30-diaminobenzidine tetrahydrochloride (DAB) (Sigma, Germany) for $30 \mathrm{~s}$ and counterstained with Mayer's haematoxylin. The staining intensities and number of sbGnRH, FSH and LH immunoreactive cells were counted, recorded, and photographed with a Canon EOS 1100D digital camera. Controls gave negative results in this experiment; the sections incubated with pre-immune rabbit serum showed no reactivity when incubated with any antibodies.

\section{Immunofluorescence detection}

The consecutive serial sections from each set of sbGnRH and GtH immunoassays were confirmed by immunofluorescence, which was processed in the same manner as immunohistochemistry, except that the secondary antibody was replaced by Alexa 488-conjugated goat anti-rabbit IgG (Molecular Probes, Eugene) at a dilution of 1:500 in blocking solution. The sections were then mounted in VECTA shield fluorescence mounting medium. The localization of sbGnRH and GtH immunoreactivities were examined and photographed by a confocal laser scanning microscope (Olympus FV 1000).

\section{sbGnRH mRNA and GtH mRNA expressions using qualitative real-time PCR (qPT-PCR)}

The sbGnRH (GenBank accession number: HQ108193) and GtH (GenBank accession number: JF495133 and JF495132) mRNA levels were investigated using qRT-PCR with the procedures from Selvaraj et al. (2012). Briefly, the brains were fixed in RNAlater (QIAGEN), and RNA extractions were performed by the manufacturer's instructions (Biotechrabbit, Hennigsdorf Germany). One step real-time RT-PCR assays were performed using gene-specific primers (Table 1). The thermocycling conditions were $95^{\circ} \mathrm{C}$ for $5 \mathrm{~min}$ and 35 cycles of $95^{\circ} \mathrm{C}$ for $10 \mathrm{~s}$ and $60^{\circ} \mathrm{C}$ for $30 \mathrm{~s}$. The PCR products were checked by $1 \%$ agarose gel electrophoresis. RNA amount was determined according to the $2^{-\Delta \Delta \mathrm{C}} \mathrm{T}$ method of Livak and Schmittgen (2001) using $\beta$-actin as a reference.

\section{Estimation of cell numbering and staining intensities}

The number of sbGnRH- and $\mathrm{GtH}$-immunoreactive (ir) cells were counted in wild $R$. brachysoma samples from non-breeding and breeding seasons on three representative slides/regions of the brain sections. Three sections on each slide were randomly selected. All numbers were represented as mean $\pm \mathrm{SD}$. According to the resulting staining intensities, a positively stained area 
190 - S. Senarat et al.

Table 1. - Gene-specific primers and amplicon size (bp) for each transcript in the quantitative real-time PCR assays.

\begin{tabular}{ccc}
\hline Transcripts & Primers & Size (bp) \\
\hline \multirow{2}{*}{$\beta$-actin* } & F - ACCGGTATTGTCATGGACTC & \multirow{2}{*}{127} \\
& R -TCATGAGGTAGTCTGTGAGGTC & \\
sbGnRH & F - CTGGACAGCCTTTCAGAC & 149 \\
& R - TCCCTGTTGGTCACACTG & \\
FSH $\beta$ & F - GTCATGGTAGCAGTGCTG & \multirow{2}{*}{131} \\
& R - CCTTCACACATGGTGGTG & \\
LH $\beta^{*}$ & F - GAAACAACCATCTGCAGCG & 100 \\
& R - AAAAGTCCCGATACGTGCAC & \\
\hline
\end{tabular}

* Note: Nyuji et al. (2012b), Selvaraj et al. (2012) ( $\mathrm{F}=$ forward and $\mathrm{R}=$ reverse primers)

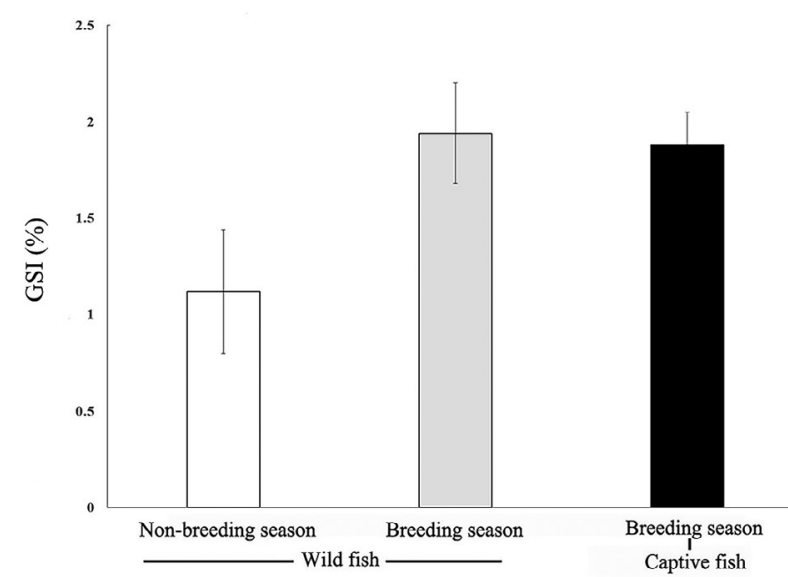

Fig. 1. - Histograms showing the gonadosomatic index (GSI), Values represent mean $\pm \mathrm{SE}$

was divided by the immunoreactivity into no immunoreactivity; +, weak immunoreactivity; ++ , medium immunoreactivity; and +++, strong immunoreactivity.

\section{Statistical analyses}

A Student t-test was employed to assess significant differences $(\mathrm{P}<0.05)$ in the number of sbGnRH- and $\mathrm{GtH}$-ir cells between non-breeding and breeding seasons. The sbGnRH and GtH mRNA levels were analysed using a one-way ANOVA followed by the least significant difference test where appropriate. These statistical tests were calculated using the Statistical Package for the Social Sciences software (version 25.0).

\section{RESULTS}

\section{Gonadosomatic index (GSI) and testicular development}

The GSI of sexually mature male $R$. brachysoma was $1.12 \pm 0.34$ and $1.94 \pm 0.26$ during the non-breeding and breeding seasons, respectively (Fig. 1). Stages of testicular development in the wild $R$. brachysoma were identified according to proportion of germ cells (Fig. 2). In wild fish, only one stage (the late spermatogenic stage,

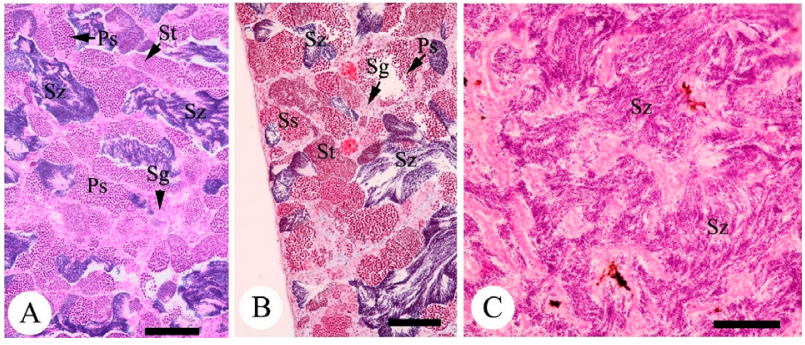

Fig. 2. - Light photomicrographs showing testicular development based on histological structures at stage 3 stained in both wild and captive Rastrelliger brachysoma (D, F). Scale bar: $100 \mu \mathrm{m}$ (B-F). Abbreviations: Ps, primary spermatocytes; Sg, spermatogonia; Ss, secondary spermatocyte; St, spermatid; Sz, spermatozoa.
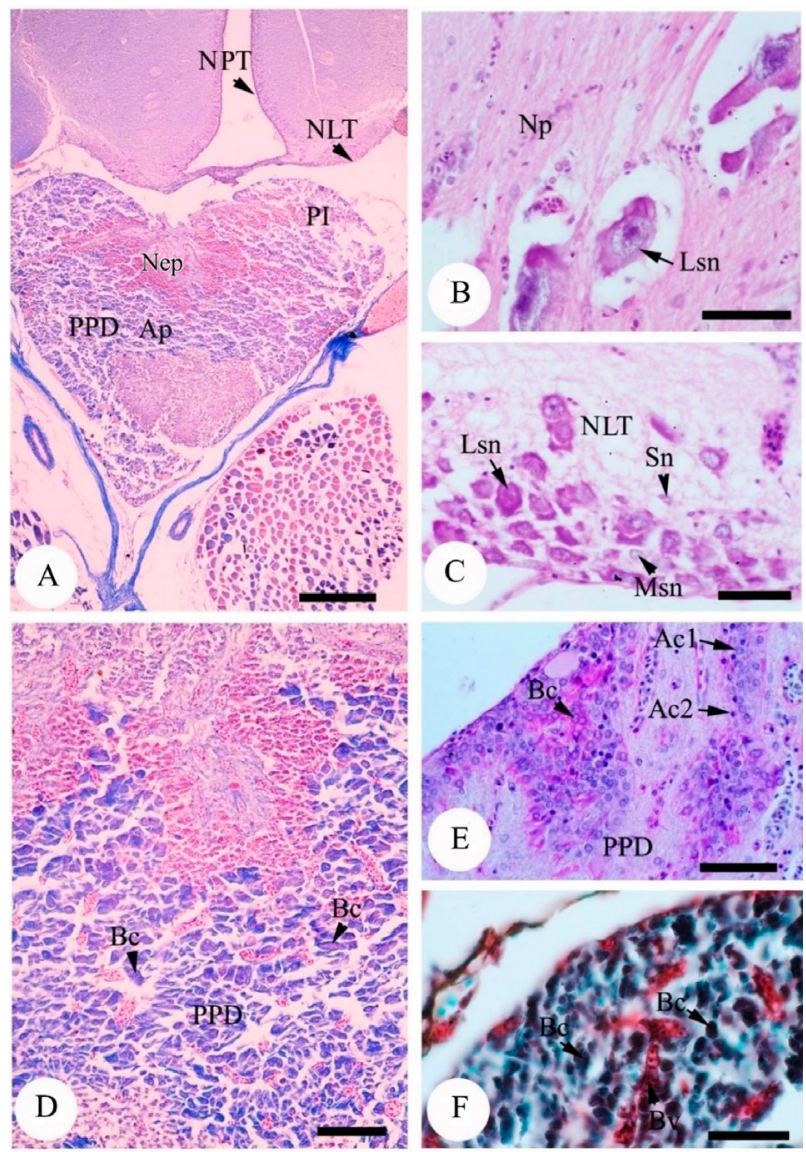

Fig. 3. - Light photomicrographs of histological structures at the level of the diencephalon (A, B, C) showing the nucleus lateralis tuberis (NLT), nucleus periventricularis (NPT) and pituitary gland (A, D, E, F). Scale bar: $50 \mu \mathrm{m}(\mathrm{B}, \mathrm{C}, \mathrm{D}-\mathrm{F}), 100 \mu \mathrm{m}(\mathrm{A})$. Abbreviations: Ac1, Acidophilic cell type; Ac2, Acidophilic cell type; Ap, adrenohypophysis; $\mathrm{Bc}$, basophilic cell; $\mathrm{Bv}$, blood vessel; Lsn, large-sized cell; Msn=medium-sized cell; Nep, neurohypophysis; Np, nucleus preopticus; PI, Pars intermedia; PPD, proximal pars distalis; Sn, small-sized cell.

stage 3) was observed in the non-breeding season. In this stage, a few spermatogonia, primary spermatocytes, secondary spermatocytes and spermatids were detected, in contrast to the advanced stage in which spermatozoa were mostly seen. Captive $R$. brachysoma had a GSI of $1.88 \pm 0.17$. Only the late spermatogenic stage was found in all samples $(n=6)$ in this group. 


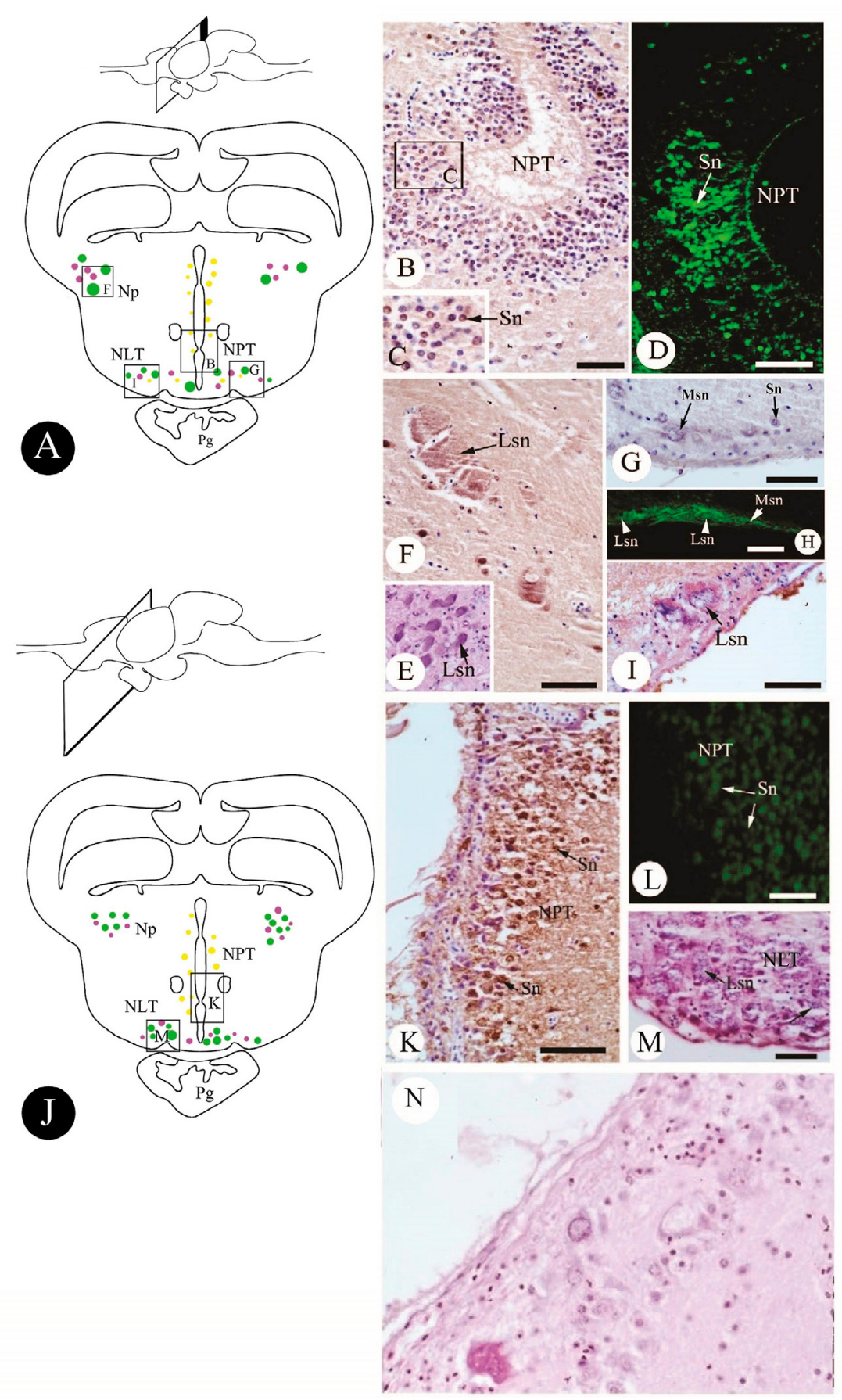

Fig. 4. - Schematic diagram and photomicrographs of Rastrelliger brachysoma comparing the non-breeding season (A-I) and the breeding season (J-N). For the non-breeding season, schematic diagram (A) and light photomicrographs (B-I) of immunolocalization of sbGnRH-ir with three areas in the diencephalon including the nucleus periventricularis (NPT) (B-C), the nucleus preopticus (Np) (E-F) and the nucleus lateralis tuberis (NLT) (G-I). For the breeding season, schematic diagram (J) and light photomicrographs of immunolocalization (K-M) of sbGnRH-ir (C-E). Negative control of sbGnRH (N) was noted. Scale bar: $50 \mu \mathrm{m}(\mathrm{B}, \mathrm{D}, \mathrm{F}, \mathrm{I}, \mathrm{K}, \mathrm{L}, \mathrm{M}), 100 \mu \mathrm{m}(\mathrm{G}, \mathrm{H})$. Abbreviations: Lsn, large-sized cell (green colour); Msn, medium-sized cell (purple colour); Pg, pituitary gland; Sn, small-sized cell (yellow colour).

\section{Histological organization of the R. brachysoma brain and pituitary gland}

The nucleus periventricularis (NPT) (Fig. 3A), nucleus lateralis tuberis (NLT) (Fig. 3A) and nucleus and preopticus (Np) (Fig. 3B) were identified. The neuronal cells from the three zones were also divided into three sizes: small, medium and large (Figs 3B-3C).
The histology and histochemistry of the male pituitary gland were observed by light microscopy. A cross section of the adenohypophysis revealed two distinct regions: the proximal par distalis (PPD) and the pars intermedia. In particular, basophils were mostly found in the PPD (Figs 3D-3F), which was previously considered to be homologous to the thyrotrope, somatotrope and gonadotrope (Shimizu et al. 2003). The number and location of baso- 


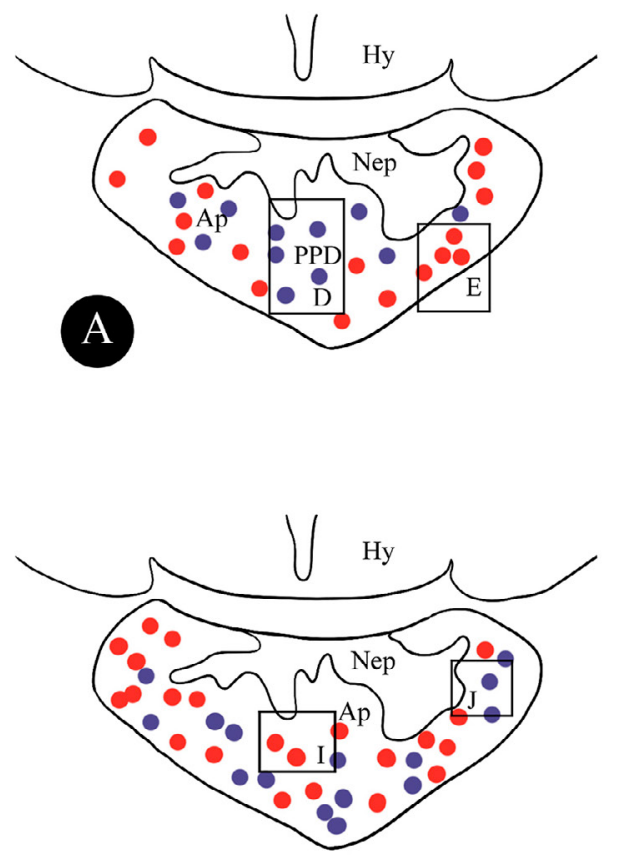

$\mathrm{H}$

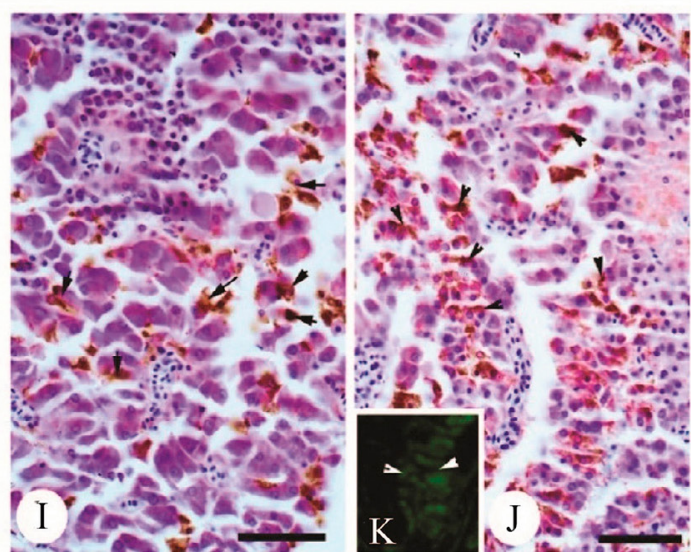

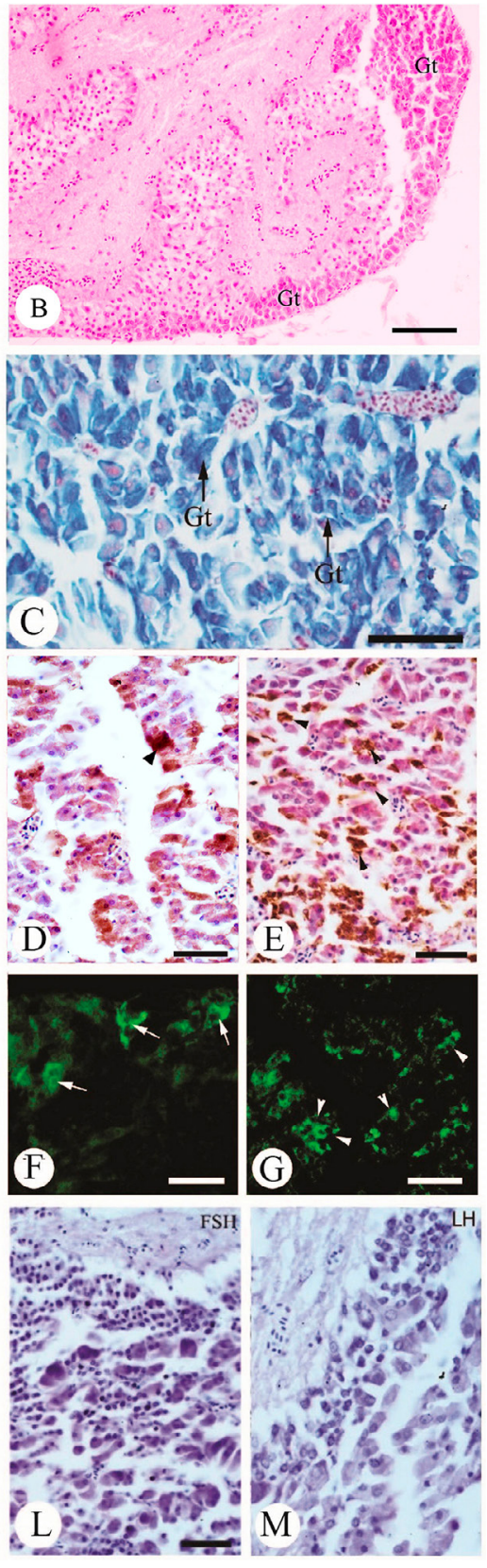

Fig. 5. - Schematic diagram (A, H) and light photomicrographs of histology (B-C) and immunolocalization of GtH-ir immunolocalization (D-J) of Rastrelliger brachysoma between the non-breeding season (D-G) and the breeding season (I-K). The anti-FSH $\beta$ (D, G, I) and antiLH $\beta$ (E, G, J, K) are visible. Negative controls including FSH (L) and LH (M) are also present. Scale bar: $20 \mu \mathrm{m}(\mathrm{C}-\mathrm{D}), 100 \mu \mathrm{m}$ (B, E, F, G). Abbreviations: Ap, adrenohypophysis; Gt, gonadotropic cell; Hy, hypothalamus; Nep, neurohypophysis; PPD, proximal pars distalis; FSH immunoreactive cell, red circle; LH immunoreactive cell, blue circle.

philic cells in male $R$. brachysoma from the non-breeding season were not significantly different from those in the males from the breeding season (data not shown).

\section{Immunohistochemistry and immunofluorescence}

Distribution of the sbGnRH-GtH immunoreactivity system in the brain of wild R. brachysoma males during sexual maturation

In the non-breeding season, immunostaining observed by light microscopy demonstrated a distinct distribution pattern of sbGnRH-ir cells in the brain of male $R$. brachysoma (Fig. 4). A strong sbGnRH-ir signal was evident in small-sized neurons in some areas of the NPT (Figs 4A-4D). In the Np, the lateral cell mass of neural cell was seen (Fig. 4E). The localization of sbGnRH-ir was also found in some of the medium- and large-sized neurons of the Np (Fig. 4F). More sbGnRH-ir cells were observed by immunohistochemistry and immunofluorescence in numerous small-, medium- and large-sized neurons of the NLT (Figs 4F-4I). These patterns were similar in the samples from the breeding season (Figs 4J-4M). Negative controls did 


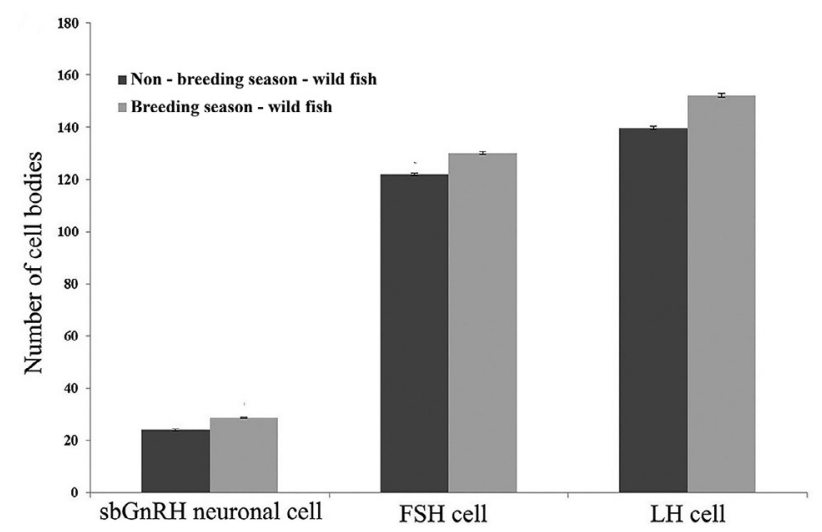

Fig. 6. - Histograms showing the mean numbers of sbGnRH-ir neurons and GtHs-ir (FSH-ir and LH-ir) cells in the brain zones of wild Rastrelliger brachysoma between non-breeding and breeding seasons. Values represent mean \pm SE; significantly different at $* \mathrm{P}<0.05$.

Table 2. - The distribution of sbGnRH neuronal clusters, FSH and LH immunoreactive cells in male Rastrelliger brachysoma.

\begin{tabular}{llllll}
\hline \multirow{2}{*}{$\begin{array}{l}\text { Stages/ } \\
\text { Seasons }\end{array}$} & \multicolumn{2}{c}{ sbGnRH neuronal clusters/ir } & FSH & LH \\
& NPT & Np & NLT & cells & cells \\
\hline \multirow{2}{*}{ Non- } & $++(\mathrm{Sn})$ & $+(\mathrm{Sn})$ & $+(\mathrm{Sn})$ & & \\
breeding & $-(\mathrm{Msn})$ & $++(\mathrm{Msn})$ & $+++(\mathrm{Msn})$ & +++ & +++ \\
& $-(\mathrm{Lsn})$ & $++(\mathrm{Lsn})$ & $++(\mathrm{Lsn})$ & & \\
& $+++(\mathrm{Sn})$ & $++(\mathrm{Sn})$ & $+(\mathrm{Sn})$ & & \\
Breeding & $-(\mathrm{Msn})$ & $+++(\mathrm{Lsn})$ & $+++(\mathrm{Msn})$ & +++ & +++ \\
& $-(\mathrm{Lsn})$ & $+++(\mathrm{Lsn})$ & $+++(\mathrm{Lsn})$ & & \\
\hline
\end{tabular}

Immunoreactivity: -, no immunoreactivity; +, weak immunoreactivity; ++ , medium immunoreactivity; +++ , strong immunoreactivity.

not result in any immunoreactive signals (Fig. 4N). In the pituitary gland, the gonadotrophs were observed in the anterior-ventral regions of the PPD (Figs 5B-5C). In the non-breeding season, the FSH-ir signal was detected, and the LH-ir signal was found in the middle-ventral regions of PPD (Figs 5D-5G). These patterns were similar in samples from the breeding season (Figs 5H-5J). Negative controls are shown for FSH-ir (Fig. 5L) and LH-ir (Fig. 5M).

\section{Numbers and staining intensities of sbGnRH-GtH-} immunoreactivities in the brain and pituitary gland

FSH and LH cells were found in the pituitary, but their numbers from the breeding season were not significantly different from those in the samples from the non-breeding season (Fig. 6, Table 2).

\section{Brain sbGnRH-GtH mRNA levels of $\mathrm{R}$. brachysoma males during sexual maturity}

There was no significant difference in expression of brain sbGnRH mRNAs between fish from the non-breeding and breeding seasons (Fig. 7). Similarly, the difference between FSH and LH mRNA levels during the breeding and the non-breeding season were not

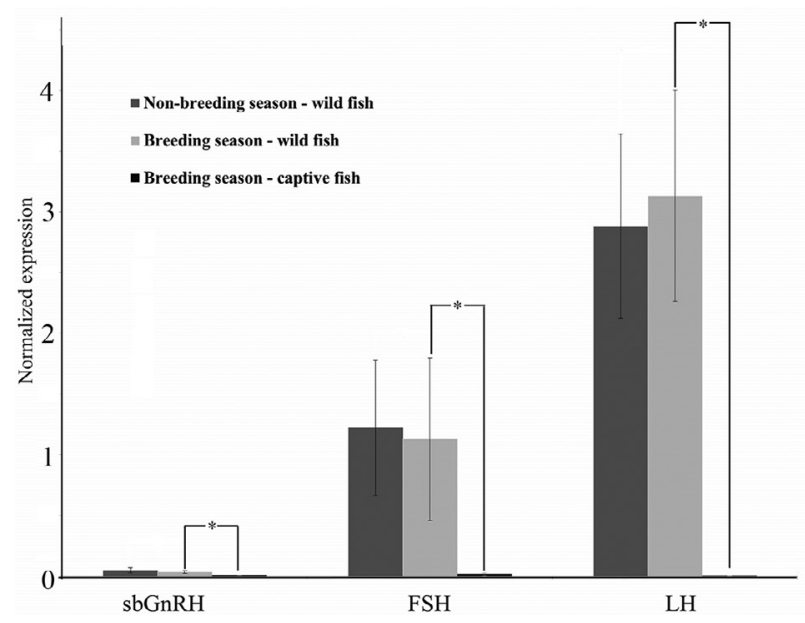

Fig. 7. - The normalized expression of gene products (sbGnRH, FSH and LH) in the brain between wild and captive Rastrelliger brachysoma. Values represent mean $\pm \mathrm{SE}$; significantly different at $* \mathrm{P}<0.05$.

statistically significant $(\mathrm{P}>0.05)$. However, wild fish had significantly higher sbGnRH-GtH mRNA levels than captive fish $(\mathrm{P}<0.05)$ (Fig. 7).

\section{DISCUSSION}

This study investigated, for the first time in male $R$. brachysoma, the presence and distribution of sbGnRH-ir cells from three brain regions, including the NPT, Np and NLT. Three types of neuronal cells, including large, medium and small-sized neurons, were sbGnRH-positive in the immunohistochemistry and immunofluorescence assay (Figs 4 and 5), indicating that these cells are involved in the production of the sbGnRH-like peptide in this fish. Several previous works also showed the occurrence of sbGnRH-ir neuronal cells in the preopticus-periventricularis nucleus of the brain in other fish species: Thunnus thynnus (Palmieri et al. 2008), Paralichthys olivaceus (Pham et al. 2007) and Scomber japonicus (Selvaraj et al. 2009). However, these studies did not identify the neuronal types, so this is the first report that has shown that the large, medium and small-sized neurons in the preopticus-periventricularis nucleus can produce the GnRH-like peptide. It could be concluded that the diencephalon is the major neuroendocrine centre that produces the sbGnRH peptide in male $R$. brachysoma. This would provide a basis for future morpho-functional research in this species.

Neuroanatomical description of the pituitary showed that this gland basically contains the PPD and the pars intermedia, as similarly seen in other fishes (Jadhao and Pinelli 2001, Shimizu et al. 2003). The gonadotropic cells were localized in the PPD but widely distributed within this area (Okuzawa et al. 1997, Amano et al. 2002, Selvaraj et al. 2009). Former observation of the sbGnRH-ir neuronal fibres in female $R$. brachysoma showed that these fibres innervated into the gonadotropic cells (Senarat et al. 2019). Thus, it is possible that these sbGnRH-ir cells regulate pituitary gonadotrophs in female $R$. brachysoma, as also reported in Pagrus major (Okuzawa et al. 1997), Verasper moseri (Amano et al. 
2002) and female Scomber japonicus (Selvaraj et al. 2009). Together with results from this study, these data emphasize the significance of the sbGnRH-GtH system in reproduction of $R$. brachysoma. This is in accordance with data from other fish: V. moseri (Amano et al. 2002), Dicentrachus labrax (González-Martínez et al. 2002) and S. japonicus (Selvaraj et al. 2009).

This study also showed that the GSIs in male $R$. brachysoma differed between the breeding and non-breeding seasons. However, testicular development was observed during both seasons, suggesting that $R$. brachysoma in the Gulf of Thailand is likely to have produced sperm during the period of this study. Further investigations on the variation in reproductive physiology of male and female $R$. brachysoma are warranted. Immunohistochemistry and qRT-PCR showed that the number of sbGnRH and GtH-ir neurons as well as GtH mRNA levels from the breeding season were not significantly different from those of the non-breeding season. However, numbers of sb$\mathrm{GnRH}$ and GtH-ir cells were consistently higher in the breeding season, suggesting that with a higher number of samples we may be able to conclude that these peptides are related to the size and maturation of the testicular tissue in $R$. brachysoma. This relationship has been implied from previous observations of other fishes, such as those of Quérat et al. (2001), Sherwood and Adams (2005) and Nyuji et al. (2011). FSH and LH are needed for differentiation and final maturation of sperm in fish (Tyler et al. 1991, Planas et al. 1993, Nyuji et al. 2011).

The wild male $R$. brachysoma showed the highest GSI value in the breeding season. On the contrary, the captive fish were compared with wild fish during the breeding season, wild fish had significantly higher levels of sbGnRH, FSH and LH mRNAs relative to captive fish. This difference suggests the presence of capture or captive-induced stress, which is consistent with previous studies (Nyuji et al. 2012a, 2013), both of which suggested that decreased GnRH-1 expression and dysfunction in the release of GtHs from the pituitary gland and enhanced oestrogen levels could be caused by stress. Similar patterns were also observed in Solea senegalesis, where the level of GnRH1 expression in captive fish was much lower than those in wild fish (Guzmán et al. 2009).

\section{CONCLUSIONS}

This paper has shown the distribution of sbGnRH and GtHs (FSH and LH) in the brain and pituitary gland in sexually mature $R$. brachysoma for the first time. Although the direct causal relationship between sbGnRH and $\mathrm{GtH}$ synthesis and reproduction has not been demonstrated in this species, this finding strongly suggests that captive $R$. brachysoma live under captive-induced environmental stress, which reduces the expression of sbGnRH and GnRH-1. Further study should focus on the interventions to up-regulate expression of $s b G n R H$ and GnRH-1 and their roles in reproduction.

\section{ACKNOWLEDGEMENTS}

Funding for this research was supported by the $100^{\text {th }}$ Anniversary Chulalongkorn University Fund for Doctoral Scholarship. We thank Dr Todd W. Miller and Assist. Prof. Dr Gen Kaneko for valuable assistance and helpful comments.

\section{REFERENCES}

Amano M., Oka Y., Yamanome T., et al. 2002. Three GnRH systems in the brain and pituitary of a pleuronectiform fish, the barfin flounder Verasper moseri. Cell Tissue Res. 309: 323-329.

https://doi.org/10.1007/s00441-002-0594-z

Bancroft J.D., Gamble M. 2008. Theory and Practice of Histological Techniques. Elsevier Health Sciences, London, $\mathrm{UK}, 725 \mathrm{pp}$.

Department of Fisheries. 2012. Fisheries Statistics of Thailand [Online]. Accessed 8 Sep. 2020.

http://164.115.22.205/it-stat/images/stories/yearbook/ yearbook2555.pdf

Department of Fisheries. 2014. Fisheries Statistics of Thailand [Online]. Accessed 8 Sep. 2020.

https://www4.fisheries.go.th/local/file_document/ 20200714140927_1_file.pdf

Dietrich D., Krieger H.O. 2009. Histological Analysis of Endocrine Disruptive Effects in Small Laboratory Fish. John Wiley \& Sons, New Jersey, USA, 341p. https://doi.org/10.1002/9780470431795

González-Martínez D., Zmora N., Mañanos E., et al. 2002. Immunohistochemical localization of three different preproGnRHs in the brain and pituitary of the European sea bass (Dicentrarchus labrax) using antibodies to the corresponding GnRH-associated peptides. J. Comp. Neurol. 446: 95-113. https://doi.org/10.1002/cne.10190

Guzmán J.M., Rubio M., Ortiz-Delgado J.B., et al. 2009. Comparative gene expression of gonadotropins (FSH and $\mathrm{LH}$ ) and peptide levels of gonadotropin-releasing hormones (GnRHs) in the pituitary of wild and cultured Senegalese sole (Solea senegalensis) broodstocks. Comp. Biochem. Physiol. A Mol. Integr. Physiol. 153: 266-277. https://doi.org/10.1016/j.cbpa.2009.02.032

Jadhao A., Pinelli C. 2001. Galanin-like immunoreactivity in the brain and pituitary of the "four-eyed" fish, Anableps anableps. Cell Tissue Res. 306: 309-318. https://doi.org/10.1007/s004410100445

King J.A., Millar R.P. 1992. Evolution of gonadotropin-releasing hormones. Trends Endocrinol. Metab. 3: 339-346. https://doi.org/10.1016/1043-2760(92)90113-F

Livak K.J., Schmittgen T.D. 2001. Analysis of relative gene expression data using realtime quantitative PCR and the 2(-Delta Delta C(T)) method. Methods 25: 402-408. https://doi.org/10.1006/meth.2001.1262

Nagahama Y. 2000. Gonadal steroid hormones: major regulators of gonadal sex differentiation and gametogenesis in fish. In: Norberg B (ed), International Symposium on the Reproductive Physiology of Fish, Proceedings of the 6th International Symposium on the Reproductive Physiology of Fish, Bergen, Norway, pp. 211-222.

Nyuji M., Shiraishi T., Selvaraj S., et al. 2011. Immunoreactive changes in pituitary $\mathrm{FSH}$ and $\mathrm{LH}$ cells during seasonal reproductive and spawning cycles of female chub mackerel Scomber japonicus. Fish Sci. 77: 731-739. https://doi.org/10.1007/s12562-011-0380-5

Nyuji M., Selvaraj S., Kitano H., et al. 2012a. Immunoreactivity of gonadotrophs (FSH and LH Cells) and gonadotropin subunit gene expression in the male chub mackerel Scomber japonicus pituitary during the reproductive cycle. Zool. Sci. 29: 623-629. https://doi.org/10.2108/zsj.29.623

Nyuji M., Shiraishi T., Kitano H., et al. 2012b. Induction of final oocyte maturation and ovulation in jack mackerel, Trachurus japonicus, temporarily reared in captivity. J. Fac. Agr. Kyushu U. 57: 427-430. https://doi.org/10.5109/25201 
Nyuji M., Fujisawa K., Imanaga Y., et al. 2013. GnRHainduced spawning of wild-caught Jack mackerel Trachurus japonicus. Fish Sci. 79: 251-258. https://doi.org/10.1007/s12562-013-0599-4

Okuzawa K., Granneman J., Bogerd J., et al. 1997. Distinct expression of GnRH genes in the red seabream brain. Fish Physiol. Biochem. 17: 71-79. https://doi.org/10.1023/A:1007760329837

Palmieri G., Acone F., Desantis S., et al. 2008. Brain morphology and immunohistochemical localization of the gonadotropinreleasing hormone in the bluefin tuna, Thunnus thynnus. Eur. J. Histochem. 52: 19-28. https://doi.org/10.4081/1182

Pham K.X., Amano M., Amiya N., et al. 2007. Immunohistochemical localization of three GnRH systems in brain and pituitary of Japanese flounder. Fish. Sci. 73: 1113-1122. https://doi.org/10.1111/j.1444-2906.2007.01443.x

Planas J.V., Swanson P., Dickhoff W.W. 1993. Regulation of testicular steroid production in vitro by gonadotropins (GTH I and GTH II) and cyclic AMP in coho salmon (Oncorhynchus kisutch). Gen. Comp. Endocrinol. 91: 8-24. https://doi.org/10.1006/gcen.1993.1099

Quérat B., Tonnerre-Doncarli C., Géniès F., et al. 2001. Duality of gonadotropins in gnathostomes. Gen. Comp. Endocrinol. 124: 308-314. https://doi.org/10.1006/gcen.2001.7715

Selvaraj S., Kitano H., Fujinaga Y., et al. 2009. Immunological characterization and distribution of three $\mathrm{GnRH}$ forms in the brain and pituitary gland of chub mackerel (Scomber japonicus). Zool. Sci. 26: 828-839. https://doi.org/10.2108/zsj.26.828

Selvaraj S., Kitano H., Amano M., et al. 2012. Molecular characterization and expression profiles of three $\mathrm{GnRH}$ forms in the brain and pituitary of adult chub mackerel (Scomber japonicus) maintained in captivity. Aquaculture 356: $200-210$. https://doi.org/10.1016/j. aquaculture. 2012.05.015

Senarat S., Kettratad J., Kangwanrangsan N., et al. 2019. The sbGnRH - GTH system in the female short mackerel,
Rastrelliger brachysoma (Bleeker, 1851), during breeding season: implications for low gamete production in captive broodstocks. Fish Physiol. Biochem. 45: 1-18

https://doi.org/10.1007/s10695-018-0509-x

Sherwood N. 1997. Origin and evolution of GnRH in vertebrates and invertebrates. In: Parhar S., Sakuma Y. (eds). GnRH Neurons: Gene to Behavior Brain Shuppan Publishing, Tokyo, pp. 3-25.

Sherwood N.M., Adams B.A. 2005. Gonadotropin-releasing hormone in fish: Evolution, expression and regulation of the GnRH gene. In: Melamed P., Sherwood N.M. (eds). Hormones and Their Receptors in Fish. Reproduction. World Scientific Publishing, Singapore, pp. 1-39. https://doi.org/10.1142/97898125691890001

Shimizu A, Yamashita M. 2002. Purification of mummichog (Fundulus heteroclitus) gonadotropins and their subunits, using an immunochemical assay with antisera raised against synthetic peptides. Gen. Comp. Endocrinol. 125: 79-91. https://doi.org/10.1006/gcen.2001.7741

Shimizu A., Tanaka H., Kagawa H. 2003. Immunocytochemical applications of specific antisera raised against synthetic fragment peptides of mummichog GtH subunits: examining seasonal variations of gonadotrophs (FSH cells and LH cells) in the mummichog and applications to other acanthopterygian fishes. Gen. Comp. Endocrinol. 132: 3545 . https://doi.org/10.1016/S0016-6480(03)00037-6

Tucker C.S., Hargreaves J.A. 2004. Biology and Culture of Cannel Catfish. Elsevier Science, 686p.

Tyler C., Sumpter J., Kawauchi H., et al.1991. Involvement of gonadotropin in the uptake of vitellogenin into vitellogenic oocytes of the rainbow trout, Oncorhynchus mykiss. Gen. Comp. Endocrinol. 84: 291-299. https://doi.org/10.1016/0016-6480(91)90052-8

Zohar Y., Mylonas C.C. 2001. Endocrine manipulations of spawning in cultured fish: from hormones to genes. Aquaculture 197: 99-136.

https://doi.org/10.1016/B978-0-444-50913-0.50009-6 